\title{
PENGARUH KINERJA KEUANGAN, GOOD CORPORATE GOVERNANCE TERHADAP NILAI PERUSAHAAN FOOD AND BEVERAGE
}

\author{
Tri Kartika Pertiwi \\ Fakultas Ekonomi, UPN Veteran Jawa Timur, Surabaya, Indonesia \\ Email: kartika_tiwi@yahoo.co.id \\ Ferry Madi Ika Pratama \\ Alumni Fakultas Ekonomi, UPN Veteran Jawa Timur, Surabaya, Indonesia
}

\begin{abstract}
Abstrak
Tujuan dari penelitian ini adalah untuk menganalisis kinerja keuangan yang diukur dengan Return on Assets (ROA) terhadap nilai perusahaan yang diukur dengan Tobin's Q serta untuk menganalisis Good Corporate Governance sebagai variabel moderasi.Obyek penelitian adalah perusahaan Food and Bevarage. Teknik yang digunakan untuk menganalisis pengaruh kinerja keuangan terhadap nilai perusahaan adalah analisis regresi linier berganda. Hasil penelitian menunjukkan kinerja keuangan berpengaruh terhadap nilai perusahaan, sedangkan Good Corporate Governance bukanlah variabel yang memoderasi hubungan kinerja keuangan dengan nilai perusahaan.
\end{abstract}

Kata Kunci: Return on Assets, Good Corporate Governance, Nilai Perusahaan.

\begin{abstract}
The purpose of this study was to analyze financial performance as measured by Return on Assets (ROA) on firm value as measured by Tobin's $Q$ as well as to analyze the Good Corporate Governance as a moderating variable. The research objects were food and beverage firms. The technique analysis was multiple linear regression analysis. The results showed that financial performance was influenced on the value of firms, while the Good Corporate Governance was not a moderating variable of the relationship between the financial performance and the firm value.
\end{abstract}

Keywords: Return on Assets, Good Corporate Governance, Firm Value.

\section{PENDAHULUAN}

Indonesia termasuk salah satu negara yang berkembang di dunia, hal ini terbukti dengan adanya pembangunan di segala bidang termasuk pembangunan sektor ekonomi. Perekonomian di Indonesia yang semakin membaik menyebabkan timbulnya gairah bagi para pengusaha untuk mengelola perusahaannya di Indonesia. Salah satu pengelolaan yang harus diperhatikan adalah masalah keuangan yang penting bagi kelangsungan hidup perusahaan, keuangan suatu perusahaan berkaitan dengan sumber dana dan penggunaannya. Semakin efisien penggunaan dan pengelolaan dana berarti semakin baik bagi perusahaan. Agar dana dalam perusahaan dapat dipenuhi secara cukup, maka dituntut adanya pengelolaan dan penentuan secara tepat terhadap sumber dana. Sumber dana dapat dipilih atau ditentukan apakah dari modal sendiri atau modal dari luar perusahaan.

Persaingan perusahaan barang konsumsi makanan dan minuman semakin lama menjadi semakin ketat sejak disahkannya organisasi perdagangan dunia. Dengan terbentuknya World Trade Organization (WTO) di tahun 1994 pasar dunia cenderung semakin terbuka dan bebas hambatan (Riyadi, 2012). Untuk itu perusahaan industri barang konsumsi makanan dan minuman di Indonesia memerlukan dana tambahan untuk menjaga kelangsungan hidup perusahaan, serta mampu bersaing dengan produk luar negeri.

Penelitian ini menggunakan perusahaan food and beverages sebagai penelitian karena saham yang berasal dari produk makanan dan minuman merupakan saham yang banyak diminati oleh investor. Saham pada perusahaan food and beverages tidak terpengaruh oleh pergerakan situasi ekonomi makro atau kondisi bisnis secara umum, perusahaan tersebut mampu memberikan bagian keuntungan yang diberikan emiten kepada pemegang sahamnya. Pasar industri makanan dan minuman diperkirakan tumbuh 7\%-10\% pada 2012. Sekjen Gabungan Pengusaha Makanan dan Minuman (Gapmmi) Franky Sibarani 
mengharapkan omzet industri makanan dan minuman akan tumbuh 8-10\% pada 2012 atau lebih besar dari pertumbuhan tahun ini yang diproyeksikan mencapai 7-8\%. Pertumbuhan tersebut, jelasnya, didorong oleh realisasi investasi-investasi baru dan kenaikan daya beli masyarakat seiring pertumbuhan ekonomi nasional (Kementerian Perindustrian, 2012).

Untuk itu, perusahaan harus memperkuat faktor internal agar dapat tetap berkembang dan bertahan. Salah satu faktor internalnya adalah perusahaan dapat melakukan pembenahan dalam manajemen untuk meningkatkan efektivitas dan efisiensi kerja atau melaksakan ekspansi usaha dalam rangka mengoptimalkan pangsa pasar yang berpotensial serta memperoleh nilai perusahaan yang tinggi.

Kinerja perusahaan yang meningkat akan berpengaruh terhadap nilai perusahaan yang akan semakin meningkat juga. Van Horne dan James (1995) menyatakan bahwa nilai perusahaan ditunjukkan oleh harga saham perusahaan yang mencerminkan keputusan investasi, pembelanjaan dan deviden. Semakin tinggi harga saham perusahaan, maka semakin tinggi pula nilai perusahaan tersebut, sebaiknya semakin rendah harga saham, maka semakin rendah pula nilai perusahaan tersebut.

Nilai perusahaan adalah sangat penting karena tujuan yang ingin dicapai manajemen keuangan adalah memaksimisasi nilai perusahaan, jika perusahaan berjalan dengan baik, maka nilai perusahaan akan meningkat atau dapat dikatakan memaksimisasi harga saham (Weston \& Copeland, 1991).

Banyak faktor yang mempengaruhi nilai perusahaan, yang mana penelitian mengenai faktorfaktor yang berpengaruh terhadap nilai perusahaan sendiri telah banyak dilakukan, antara lain kinerja keuangan suatu perusahaan, kebijakan deviden, corporate governance dan lain sebagainya.

Untuk mengukur tingkat pengembalian terhadap aset yang dikeluarkan perusahaan. dapat dilakukan dengan menghitung Return on asset (ROA). Penelitian mengenai pengaruh kinerja keuangan dalam hal ini ROA terhadap nilai perusahaan menunjukkan hasil yang tidak konsisten. ROA yang positif menunjukkan bahwa dari total aktiva yang dipergunakan untuk beroperasi, perusahaan mampu memberikan laba bagi perusahaan. Sebaliknya apabila ROA yang negatif menunjukkan bahwa perusahaan mengalami kerugian. Jadi jika suatu perusahaan mempunyai ROA yang tinggi maka perusahaan tersebut berpeluang besar dalam meningkatkan pertumbuhan. Akan tetapi, jika total aktiva yang digunakan perusahaan tidak memberikan laba artinya perusahaan akan mengalami kerugian dan akan menghambat pertumbuhan. Semakin tinggi ROA menunjukkan semakin baik kinerja perusahaan, karena dana yang diinvestasikan ke dalam aset dapat menghasilkan Earning After Tax (EAT) yang semakin tinggi (Ang, 1997).

Namun, hasil yang berbeda diperoleh oleh Kaaro (2002) dalam Suranta dan Merdistuti (2004) dalam penelitiannya menemukan bahwa Return on Assets (ROA) justru berpengaruh negatif terhadap nilai perusahaan. Hal ini menunjukkan adanya faktor lain yang turut mempengaruhi hubungan Return on Assets (ROA) dengan nilai perusahaan. Good Corporate Governance (GCG) sebagai variabel pemoderasi diduga ikut memperkuat atau memperlemah pengaruh tersebut.

Beberapa tahun terakhir banyak perusahaan semakin menyadari pentingnya menerapkan program Good Corporate Governance (GCG) sebagai bagian dari strategi bisnisnya. Hal tersebut merupakan suatu faktor yang dapat mempengaruhi nilai perusahaan. Masalah Corporate Governace muncul karena terjadinya pemisahan antara kepemilikan dan pengendalian perusahaan. Pemisahan ini didasarkan pada Teori Agensi (Agency Theory) yang dalam hal ini manajemen cenderung akan meningkatkan keuntungan pribadinya daripada tujuan perusahaan. Oleh sebab itu, selain memiliki kinerja keuangan yang baik perusahaan juga diharapkan memiliki tata kelola (Corporate Governance) yang baik. Tata kelola perusahaan yang baik menggambarkan bagaimana usaha manajemen mengelola aset dan modalnya dengan baik agar menarik para investor. Pengelolaan aset dan modal suatu perusahaan dapat dilihat dari kinerja keuangan yang ada. Jika pengelolaannya dilakukan dengan baik maka, otomatis akan meningkatkan nilai perusahaan. Adapun tujuan penelitian ini adalah untuk mengetahui pengaruh kinerja keuangan terhadap nilai perusahaan dengan variabel pemoderasi Good Corporate Governance.

Penelitian terdahulu tentang pengaruh Good Corporate Governance terhadap hubungan antara kinerja keuangan dengan nilai perusahaan yang diteliti Carningsih (2009). Hasil penelitian menunjukkan bahwa pada Return on Assets (ROA) terbukti berpengaruh negatif terhadap nilai perusahaan, sedangkan Return on Equity (ROE) tidak berpengaruh terhadap nilai perusahaan property dan real estate terdaftar di Bursa Efek Indonesia selama tahun 20072008. Proporsi Komisaris Independen sebagai proksi dari Good Corporate Governance merupakan variabel moderasi tidak terbukti berpengaruh terhadap nilai perusahaan. Dalam penelitian tersebut bahwa komisaris independen sebagai variabel moderasi atas hubungan kinerja keuangan terhadap nilai perusahaan tidak mampu memoderasi hubungan kedua variabel tersebut. 
Penelitian yang dilakukan Midiastuti et al. (2003) di Indonesia kepemilikan manajerial mampu menjadi mekanisme Good Corporate Governance yang mampu mengurangi masalah ketidak selarasan kepentingan antara manajer dengan pemilik atau pemegang saham atau dapat dikatakan semakin meningkat proporsi kepemilikan saham manajerial maka semakin baik kinerja perusahaan.

\section{LANDASAN TEORI DAN HIPOTESIS}

\section{Nilai Perusahaan}

Tujuan pokok yang ingin dicapai perusahaan adalah memaksimumkan nilai perusahaan. Tujuan tersebut dipergunakan karena dengan memaksimumkan nilai perusahaan maka pemilik perusahaan akan menjadi lebih makmur atau menjadi semakin kaya (Husnan, 2000). Nilai perusahaan sangat penting karena dengan nilai perusahaan yang tinggi akan diikuti oleh tingginya kemakmuran pemegang saham (Brigham \& Gapenski, 1996). Semakin tinggi harga saham maka semakin tinggi pula nilai perusahaan. Nilai perusahaan yang tinggi menjadi keinginan para pemilik perusahaan, sebab dengan nilai yang tinggi menunjukan kemakmuran pemegang saham juga tinggi. Kekayaan pemegang saham dan perusahaan dipresentasikan oleh harga pasar dari saham yang merupakan cerminan dari keputusan investasi, pendanaan (financing), dan manajemen aset.

\section{Kinerja Keuangan}

Kinerja keuangan merupakan salah satu faktor yang menunjukkan efektivitas dan efisiensi suatu organisasi dalam rangka mencapai tujuannya. Efektivitas apabila manajemen memiliki kemampuan untuk memilih tujuan yang tepat atau suatu alat yang tepat untuk mencapai tujuan yang telah ditetapkan. Efisiensi diartikan sebagai ratio (perbandingan) antara masukan dan keluaran yaitu dengan masukan tertentu memperoleh keluaran yang optimal.

Ada kalanya kinerja keuangan mengalami penuruan. Untuk memperbaiki hal tersebut, salah satu caranya adalah mengukur kinerja keuangan dengan menganalisa laporan keuangan menggunakan rasiorasio keuangan. Hasil pengukuran terhadap pencapaian kinerja dijadikan dasar bagi manajemen atau pengelola perusahaan untuk perbaikan kinerja pada periode berikutnya dan dijadikan landasan pemberian reward and punishment terhadap manajer dan anggota organisasi. Pengukuran kinerja yang dilakukan setiap periode waktu tertentu sangat bermanfaat untuk menilai kemajuan yang telah dicapai perusahaan dan menghasilkan informasi yang sangat bermanfaat untuk pengambilan keputusan manajemen serta mampu menciptakan nilai perusahaan itu sendiri kepada para stakeholder.

\section{Good Corporate Governance}

Konsep Good Corporate Governance (GCG) adalah konsep yang sudah saatnya diimplementasikan dalam perusahaan-perusahaan yang ada di Indonesia, karena melalui konsep yang menyangkut struktur perseroan, yang terdiri dari unsur-unsur RUPS, direksi dan komisaris dapat terjalin hubungan dan mekanisme kerja, pembagian tugas, kewenangan dan tanggung jawab yang harmonis, baik secara intern maupun ekstern dengan tujuan meningkatkan nilai perusahaan demi kepentingan shareholders dan stakeholders.

GCG diperlukan untuk mendorong terciptanya pasar yang efisien, transparan dan konsisten dengan peraturan perundang-undangan. Penerapan GCG perlu didukung oleh tiga pilar yang saling berhubungan, yaitu negara dan perangkatnya sebagai regulator, dunia usaha sebagai pelaku pasar, dan masyarakat sebagai pengguna produk dan jasa dunia usaha.

Good Corporate Governance (Tata kelola perusahaan) adalah rangkaian proses, kebiasaan, kebijakan, aturan dan institusi yang memengaruhi pengarahan, pengelolaan, serta pengontrolan suatu perusahaan atau korporasi. Tata kelola perusahaan juga mencakup hubungan antara para pemangku kepentingan (stakeholder) yang terlibat serta tujuan pengelolaan perusahaan. Pihak-pihak utama dalam tata kelola perusahaan adalah pemegang saham, manajemen dan dewan direksi. Tata Kelola Perusahaan adalah suatu subyek yang memiliki banyak aspek. Salah satu topik utama dalam tata kelola perusahaan adalah menyangkut masalah akuntabilitas dan tanggung jawab, khususnya implementasi pedoman dan mekanisme untuk memastikan perilaku yang baik dan melindungi kepentingan pemegang saham. Fokus utama lain adalah efisiensi ekonomi yang menyatakan bahwa sistem tata kelola perusahaan harus ditujukan untuk mengoptimalisasi hasil ekonomi dengan penekanan kuat pada kesejahteraan para pemegang saham. Ada pula sisi lain yang merupakan subyek dari tata kelola perusahaan, seperti sudut pandang pemangku kepentingan yang menunjuk perhatian dan akuntabilitas lebih terhadap pihakpihak lain selain pemegang saham, misalnya karyawan atau lingkungan (Haidar, 2009)

Inti dari kebijakan tata kelola perusahaan adalah agar pihak-pihak yang berperan dalam menjalankan perusahaan memahami dan menjalankan fungsi dan peran sesuai wewenang dan tanggung jawab. Pihak yang berperan meliputi pemegang saham, dewan komisaris, komite, direksi, pimpinan unit dan karyawan. 


\section{Prinsip-prinsip dalam Good Corporate Gover- nance (GCG)}

Dalam Undang-Undang No 40 Tahun 2007 oleh Kementerian Hukum dan HAM Republik Indonesia tentang Perseroan Terbatas dan prinsip tata kelola perseroan yang baik (Good Corporate Governance) dalam menjalankan perusahaan, dan dalam Keputusan Menteri BUMN Tahun 2002 tentang prinsipprinsip Good Corporate Governance harus mencerminkan pada hal-hal sebagai berikut:

a) Transparansi, yaitu keterbukaan dalam melaksanakan proses pengambilan keputusan dan keterbukaan dalam mengemukakan informasi materiil dan relevan mengenahi perusahaan.

b) Kemandirian, yaitu suatu keadaan yang mana perusahaan dikelola secara profesional tanpa benturan kepentingan dan pengaruh/ tekanan dari pihak manapun yang tidak sesuai dengan peraturan perundang-undangan yang berlaku dan prinsipprinsip korporasi yang sehat.

c) Akuntabilitas, yaitu kejelasan fungsi, pelaksanaan dan pertanggung jawaban organ sehingga pengelolaan perusahaan terlaksana secara efektif.

d) Pertanggung jawaban, yaitu kesesuaian di dalam pengelolaan perusahaan terhadap peraturan perundang-undangan yang berlaku dan prinsipprinsip korporasi yang sehat.

e) Kewajaran (fairness) yaitu keadilan dan kesetaraan di dalam memenuhi hak-hak stakeholder yang timbul berdasarkan perjanjian dan peraturan perundang-undangan yang berlaku.

Untuk mewujudkan terciptanya Good Corporate Governance, prinsip-prinsip tersebut harus dapat dicapai oleh perusahaan dengan adanya kerja sama yang baik dari berbagai pihak, baik di dalam maupun luar perusahaan sesuai dengan standar dan peraturan yang berlaku untuk dapat memberikan manfaat kepada kondisi keuangan perusahaan.

\section{Faktor Penerapan Good Corporate Governance}

Keberhasilan penerapan Good Corporate Governance juga mempunyai prasyarat tersendiri. Menurut Daniri (2005) ada dua faktor yang memegang peranan, faktor ekternal dan internal. Faktor Eksternal yaitu beberapa faktor yang berasal dari luar perusahaan yang sangat mempengaruhi keberhasilan penerapan GCG. Di antaranya: a) Terdapatnya sistem hukum yang baik sehingga mampu menjamin berlakunya supremasi hukum yang konsisten dan efektif. b) dukungan pelaksanaan GCG dari sektor publik/lembaga pemerintahaan yang diharapkan dapat pula melaksanakan Good Governance dan Clean Government menuju Good Government Governance yang sebenarnya. c) Terdapatnya contoh pelaksanaan GCG yang tepat (best practices) yang dapat menjadi standar pelaksanaan GCG yang efektif dan profesional. Dengan kata lain, semacam benchmark (acuan).

Faktor Internal adalah pendorong keberhasilan pelaksanaan praktek GCG yang berasal dari dalam perusahaan. Beberapa faktor dimaksud antara lain: a) terdapatnya budaya perusahaan (corporate culture) yang mendukung penerapan GCG dalam mekanisme serta sistem kerja manajemen di perusahaan. b) berbagai peraturan dan kebijakan yang dikeluarkan perusahaan mengacu pada penerapan nilai-nilai GCG. c) manajemen pengendalian risiko perusahaam juga didasarkan pada kaidah-kaidah standar GCG. d) terdapatnya sistem audit (pemeriksaan) yang efektif dalam perusahaan untuk menghindari setiap penyimpangan yang mungkin akan terjadi. e) adanya keterbukaan informasi bagi publik untuk mampu memahami setiap gerak dan langkah manajemen dalam perusahaan sehingga kalangan publik dapat memahami dan mengikuti setiap derap langkah perkembangan dan dinamika perusahaan dari waktu ke waktu.

\section{Kepemilikan Manajerial}

Beberapa penelitian (Kang \& Shivdasani, 1995; Yafeh \& Yosha, 1996) menunjukkan bahwa di banyak negara perusahaan besar memiliki pemegang saham besar dan pemegang saham aktif dalam tata kelola perusahaan (dalam La Porta et al., 1999). Jika pemegang saham merangkap pengelola peruahaan akan mengurangi konflik keagenan. Jensen dan Meckling (1976) menyatakan bahwa kepemilikan saham yang besar dari segi nilai ekonomisnya memiliki insentif untuk memonitor. Permasalahan keagenan diasumsikan akan hilang apabila seorang manajer adalah juga sekaligus sebagai seorang pemilik. Secara teoritis ketika kepemilikan manajemen rendah, maka insentif terhadap kemungkinan terjadinya perilaku opportunistik manajer akan meningkat. Pengertian kepemilikan manajerial menurut Wahidahwati (2002) sebagai berikut: Kepemilikan manajerial merupakan pemegang saham dari pihak manajemen yang secara aktif ikut dalam pengambilan keputusan perusahaan (Direksi dan Komisaris). Kepemilikan manajerial bisa diukur dari jumlah persentase saham yang dimiliki manajemen. Kepemilikan manajerial cukup kuat dalam melaksanakan Good Corporat Governance, karena berperan penting dalam penerapan Good Corporate Governance dengan prinsipprinsip yang sudah ada. Dewan Komisaris turut mengawasi dan memberikan pengarahan tentang 
kebijakan Direksi dan hal umum yang berkaitan dengan perusahaan dan kegiatan usahanya, serta memberikan nasihat kepada Direksi jika diperlukan. Dalam melaksanakan tugasnya, anggota Dewan Komisaris bertindak sepenuhnya untuk kepentingan perusahaan dan para pemangku kepentingan lainnya. Kemampuan Dewan Komisaris untuk mengawasi merupakan fungsi yang positif dari porsi dan independensi dari Dewan Komisaris eksternal. Dewan komisaris juga bertanggung jawab atas kualitas laporan yang disajikan. Jensen (1993) dan Lipton dan Lorsch (1992) merupakan yang pertama menyimpulkan bahwa Dewan Komisaris merupakan bagian dari mekanisme Corporate Governance (dalam Beiner et al., 2003). Hal ini diperkuat oleh pendapat Allen dan Gale (dalam Beiner et al., 2003) yang menegaskan bahwa Dewan Komisaris merupakan mekanisme governance yang penting. Direksi bertanggung jawab penuh dalam melaksanakan tugasnya untuk kepentingan perusahaan dalam mencapai maksud dan tujuannya. Setiap anggota Direksi wajib dengan itikad baik dan penuh tanggung jawab dalam menjalankan tugasnya dengan mengindahkan peraturan perundang undangan yang berlaku atau sesuai dengan kode etik usaha. Kode etik usaha merupakan kebijakan perusahaan bahwa seluruh karyawan dan direksi harus berperilaku sesuai dengan standar etika yang tinggi dengan demikian melayani kepentingan terbaik perusahaan, karyawan, dan masyarakat luas yang menjadi bagiannya. Hal tersebut akan dilaksanakan sesuai dengan prinsip transparency, responsibility, accountability, dan fairness.

\section{Teori Agensi (Principal-Agency Theory)}

Teori Keagenan (agency theory) memunculkan argumentasi terhadap adanya konflik antara pemilik yaitu pemegang saham dengan para manajer. Konflik tersebut muncul sebagai akibat perbedaan kepentingan di antara kedua belah pihak. Hubungan keagenan (agency relationship) terjadi ketika satu atau lebih individu, yang disebut sebagai prinsipal menyewa individu atau organisasi lain, yang disebut sebagai agen, untuk melakukan sejumlah jasa dan mendelegasikan kewenangan untuk membuat keputusan kepada agen tersebut (Brigham \& Houston, 2006). Kepemilikan diwakili oleh investor mendelegasikan kewenangan kepada agen dalam hal ini manajer untuk mengelola kekayaan investor. Investor mempunyai harapan bahwa dengan mendelegasikan wewenang pengelolaan tersebut akan memperoleh keuntungan dengan bertambahnya kekayaan dan kemakmuran investor.

Hubungan keagenan dapat menimbulkan masalah pada saat pihak-pihak yang bersangkutan mempunyai tujuan yang berbeda. Pemilik modal menghendaki bertambahnya kekayaan dan kemakmuran para pemilik modal, sedangkan manajer juga menginginkan bertambahnya kesejahteraan bagi para manajer, sehingga muncullah konflik kepentingan antara pemilik (investor) dengan manajer (agen). Pemilik lebih tertarik untuk memaksimumkan return dan harga sekuritas dari investasinya, sedangkan manajer mempunyai kebutuhan psikologis dan ekonomi yang luas, termasuk memaksimumkan kompensasinya

Jensen dan Meckling (1976) mendefinisikan hubungan keagenan sebagai suatu kontrak antara manajer (agent) dan pemilik (principal) perusahaan. Satu atau lebih principal memberi wewenang dan otoritas kepada agent untuk melakukan kepentingan. Dalam suatu korporasi, yang disebut principal adalah pemegang saham dan yang dimaksud agen adalah manajemen yang mengelola perusahaan. Agency theory muncul berdasarkan adanya fenomena pemisahan antara pemilik perusahaan (pemegang saham/owner) dengan para manajer yang mengelola perusahaan.

Dalam perkembangan selanjutnya, Agency Theory mendapat respons lebih luas karena dipandang lebih mencerminkan kenyataan yang ada. Berbagai pemikiran mengenai Corporate Governance berkembang dengan bertumpu pada Agency Theory yang mana pengelolaan perusahaan harus diawasi dan dikendalikan untuk memastikan bahwa pengelolaan dilakukan dengan penuh kepatuhan kepada berbagai peraturan dan ketentuan yang berlaku (Solihin, 2009). Sehubungan dengan teori keagenan, maka pihak yang paling berkepentingan terhadap kinerja manajemen adalah pemilik (shareholders). Untuk kepentingan pemilik itulah dewan komisaris dibentuk dan salah satu cara yang dapat dilakukan oleh pemilik untuk memastikan bahwa manajemen mengelola perusahaan dengan baik adalah dengan mekanisme Corporate Governance yang tepat. Dengan mekanisme Corporate Governance yang tepat diharapkan manajemen akan dapat memenuhi tanggungjawabnya sehubungan dengan kepentingan pemilik.

\section{Kerangka Konseptual}

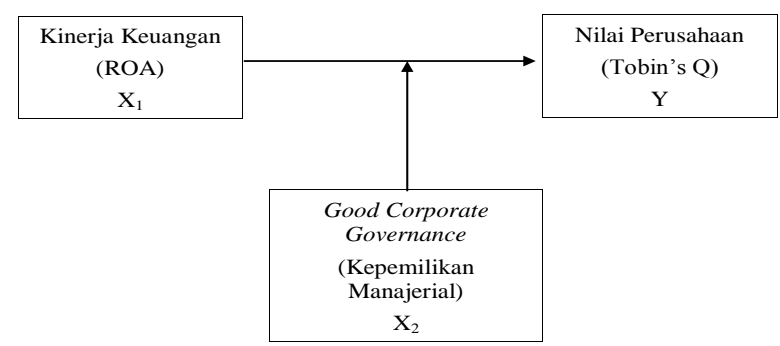

Gambar 1. Kerangka Konseptual 
Sesuai dengan kerangka konseptual di atas maka penelitian ini akan menguji hipotesis yang pertama, diduga bahwa Kinerja keuangan mempunyai pengaruh positif terhadap nilai perusahaan food and beverages yang terdaftar di Bursa Efek Indonesia. Kedua menguji hipotesis diduga bahwa Good Corporate Governance mampu memoderasi pengaruh kinerja keuangan terhadap nilai perusahaan food and beverages yang terdaftar di Bursa Efek Indonesia.

\section{METODE PENELITIAN}

Variabel dependen dalam penelitian ini adalah nilai perusahaan. Pengukuran nilai perusahaan menggunakan Tobin's Q yang dikembangkan Klapper dan Love (dalam Hidayah, 2008). Tobin's Q dihitung dengan rumus, sebagai berikut:

$Q=\frac{((C P x \text { Jumlah sahamberedar })+(T L+1))-C A}{T A}$

Keterangan:

$\mathrm{Q}=$ Nilai Perusahaan

$\mathrm{CP}=$ Closing Price

$\mathrm{TL}=$ Total Liabilities

I = Inventory

$\mathrm{CA}=$ Current Assets

$\mathrm{TA}=$ Total Assets

Variabel independen yaitu kinerja keuangan diukur dengan Return on Assets (ROA). Indikator ini digunakan untuk mengukur kemampuan total aktiva dalam menghasilkan keuntungan. Menurut Brigham \& Houston (2006) secara sistematis, ROA dapat dihitung dengan rumus:

$R O A=\frac{\text { Laba bersih seteah pajak }}{\text { Total Asset }} \times 100 \%$

Variabel Pemoderasi, adalah variabel yang mempengaruhi (baik memperlemah atau memperkuat) hubungan (agency effect) antara variabel independen ke variabel dependen. Variabel pemoderasi dalam penelitian ini adalah Good Corporate Governance yang diproksikan dengan kepemilikan manajerial.

Kepemilikan Manajerial $=$

Kepemimpinan saham oleh direktur dan komisaris

Jumlah saham beredar

Teknik penentuan sampel yang digunakan dalam penelitian ini adalah purposive sampling, yang berarti pemilihan sampel berdasarkan kriteria tertentu.
Terdapat 12 perusahaan makanan dan minuman yang memenuhi kriteria pengambilan sampel pada tahun 2008 hingga 2010. Berdasarkan metode purposive sampling dan kriteria-kriteria: perusahaan mempublikasikan laporan keuangan secara berturut-turut selama tahan 2005 sampai dengan tahun 2010, perusahaan memiliki data mengenahi kepemilikan saham manajerial. Pengambilan sampel yang telah ditetapkan, maka diperoleh sampel akhir sebanyak 4 perusahaan dengan 6 periode, maka didapat 24 data. Sampel yang dijadikan obyek penelitian perusahaan food and beverages dari tahun 2005 sampai dengan tahun 2010, antara lain: PT. Indofood Sukses Makmur Tbk., PT. Prasidha Aneka Niaga Tbk., PT. Sekar Laut Tbk., PT. Siantar Top Tbk.

Jenis Data yang digunakan adalah data sekunder yaitu penggunaan data yang berasal dari dokumendokumen yang sudah ada. Untuk menguji apakah ROA berpengaruh terhadap nilai perusahaan, dan menguji apakah pengungkapan kepemilikan manajerial mempunyai pengaruh terhadap hubungan antara ROA dengan nilai perusahaan, maka pengujian dalam penelitian ini dapat dilakukan sebagai berikut:

Pengujian parsial (Uji-t), Pengujian ini dilakukan untuk mengetahui variabel bebas (kinerja keuangan) secara parsial berpengaruh signifikan terhadap variabel moderasi (Good Corporate Governance) dan untuk mengetahui variabel bebas dan variabel moderating secara parsial mempunyai pengaruh yang signifikan terhadap variabel terikat (nilai perusahaan).

Uji ketepatan model (Uji F), menunjukkan apakah persamaan regresi yang terbentuk memiliki ketepatan model (gooness of fit) yang tinggi.

\section{HASIL PENELITIAN DAN PEMBAHASAN}

\section{Nilai Perusahaan}

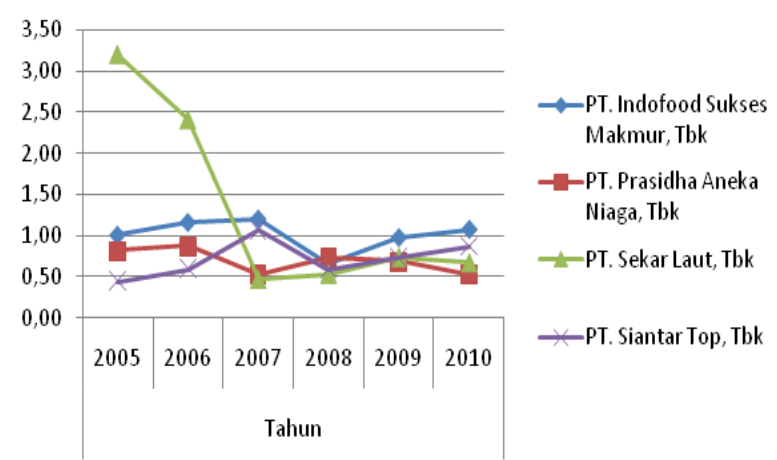

Sumber: Data Diolah

Gambar 2. Kurva Nilai Perusahaan pada Perusahaan Food and Beverages Tahun 2005 - Tahun 2010 
Berdasarkan grafik nilai perusahaan, dapat diketahui bahwa PT. Sekar Laut, Tbk. memiliki nilai perusahaan yang cenderung berbeda dengan ketiga perusahaan lainnya (PT. Indofood Sukses Makmur, Tbk., PT. Prasidha Aneka Niaga, Tbk. dan PT. Siantar Top, Tbk.). Terbukti PT. Sekar Laut, Tbk. memiliki nilai perusahaan terbesar di tahun 2005 dan 2006, sedangkan tahun 2007 dan 2008 cenderung memiliki nilai perusahaan terendah serta tahun 2009 dan 2010 PT. Sekar Laut, Tbk. adalah perusahaan yang memiliki nilai perusahaan terendah kedua setelah PT. Prasidha Aneka Niaga, Tbk.

\section{Return on Assets}

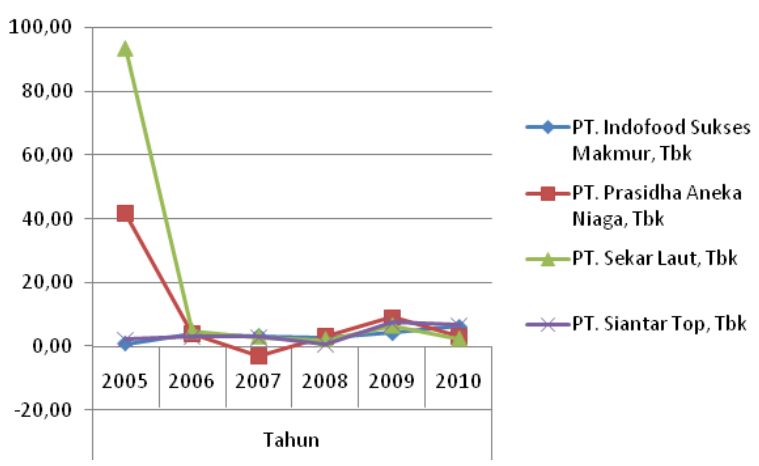

Sumber: Data Diolah

Gambar 3. Kurva Return On Assets pada Perusahaan Food and Beverages Tahun 2005 - Tahun 2010

Berdasarkan kurva Return on Assets, dapat diketahui bahwa PT. Sekar Laut, Tbk. memiliki Return On Assets yang cenderung berbeda dengan ketiga perusahaan lainnya (PT. Indofood Sukses Makmur, Tbk., PT. Prasidha Aneka Niaga, Tbk. dan PT. Siantar Top, Tbk.). Terbukti PT. Sekar Laut, Tbk. memiliki Return on Assets terbesar di tahun 2005 dan 2006, sedangkan tahun 2010 cenderung memiliki Return on Assets terendah serta tahun 2008 dan 2009 PT. Sekar Laut, Tbk. adalah perusahaan yang memiliki Return on Assets terendah ketiga setelah PT. Indofood Sukses Makmur, Tbk. dan PT. Siantar Top, Tbk.

\section{Good Corporate Governance}

Berdasarkan kurva Good Corporate Governance, nampak bahwa PT. Siantar Top, Tbk. memiliki Return on Assets yang cenderung berbeda dengan ketiga perusahaan lainnya (PT. Indofood Sukses Makmur, Tbk., PT. Prasidha Aneka Niaga, Tbk. dan PT. Sekar Laut, Tbk.). Terbukti PT. Siantar Top, Tbk. memiliki Good Corporate Governance terbesar di tahun 2005 sampai dengan 2010, kecuali tahun 2008 cenderung memiliki Good Corporate Governance terendah.

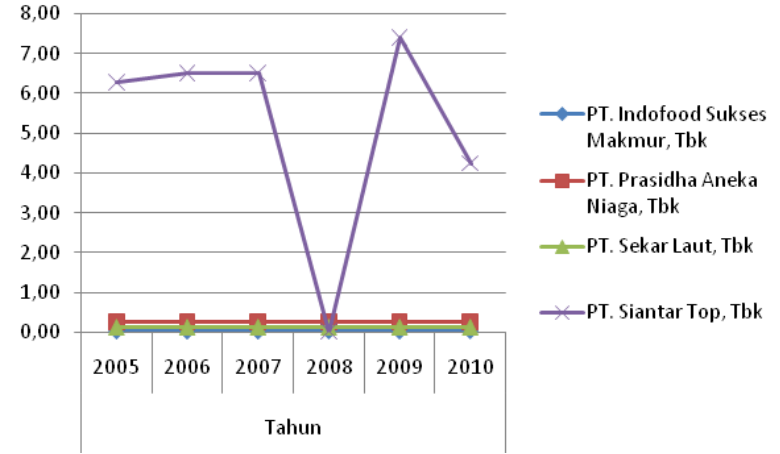

Sumber: Data Diolah

Gambar 4. Kurva Good Corporate Governance pada Perusahaan Food and Beverages Tahun 2005-Tahun 2010

Pembahasan

Tabel 1. Hasil Pengaruh Kinerja Keuangan $\left(\mathbf{X}_{1}\right)$, Good Corporate Governance $\left(\mathrm{X}_{2}\right)$ dan Interaksi $\left(\mathrm{X}_{1} \cdot \mathrm{X}_{2}\right)$ Terhadap Nilai Perusahaan (Y)

\begin{tabular}{ccccc}
\hline Model & Nilai & Signifikansi & Arah & Pengaruh \\
\hline$\left(\mathrm{X}_{1}\right)$ & 0,023 & 0,000 & + & Pengaruh \\
$\left(\mathrm{X}_{2}\right)$ & $-0,004$ & 0,959 & - & tidak \\
$\left(\mathrm{X}_{1} \mathrm{X}_{2}\right)$ & $-0,004$ & 0,777 & - & tidak \\
\hline
\end{tabular}

Keterangan:

$\mathrm{Y}=$ Nilai Perusahaan

$\mathrm{X}_{1}=$ Kinerja Keuangan

$\mathrm{X}_{2}=$ Good Corporate Governance

$\mathrm{X}_{1} \mathrm{X}_{2}=$ Interaksi Kinerja Keuangan dan Good Corporate Governance

Persamaan regresi yang dihasilkan adalah sebagai berikut:

$Y=0,766+0,023 X_{1}-0,004 X_{2}-0,004 X_{1} X_{2}$

Hasil uji t dapat dijelaskan sebagai berikut:

Nilai koefisien regresi $X_{1}$ sebesar 0,023 dengan tingkat signifikan sebesar 0,000 kurang dari 5\% (sig < $5 \%$ ) maka $\mathrm{H}_{0}$ ditolak dan $\mathrm{H}_{1}$ diterima yang berarti kinerja keuangan $\left(\mathrm{X}_{1}\right)$ secara parsial berpengaruh signifikan terhadap nilai perusahaan (Y). Nilai koefisien regresi pada variabel kinerja keuangan bertanda positif, yang artinya kinerja keuangan berpengaruh positif signifikan terhadap nilai perusahaan, sehingga hipotesis ke-1 "Diduga bahwa Kinerja keuangan mempunyai pengaruh positif terhadap nilai perusahaan food and beverages yang terdaftar di Bursa Efek Indonesia", teruji kebenarannya.

Nilai koefisien regesi variabel Good Corporate Governance $\left(\mathrm{X}_{2}\right)$ sebesar $-0,004$ dengan tingkat signifikan sebesar 0,959 lebih dari 5\% (sig > 5\%) maka $\mathrm{H}_{0}$ diterima dan $\mathrm{H}_{1}$ ditolak yang berarti Good Corporate Governance $\left(\mathrm{X}_{2}\right)$ secara parsial tidak berpengaruh signifikan terhadap nilai perusahaan $(\mathrm{Y})$. 
Nilai koefisien regresi interaksi antara kinerja keuangan dan Good Corporate Governance $\left(\mathrm{X}_{1} \mathrm{X}_{2}\right)$ terhadap nilai perusahaan sebesar $-0,004$ dengan tingkat signifikan sebesar 0,777 lebih dari 5\% (sig > $5 \%$ ) maka $\mathrm{H}_{0}$ diterima dan $\mathrm{H}_{1}$ ditolak yang berarti interaksi antara kinerja keuangan $\left(\mathrm{X}_{1}\right)$ dan Good Corporate Governance $\left(\mathrm{X}_{2}\right)$ secara parsial tidak berpengaruh signifikan terhadap nilai perusahaan $(\mathrm{Y})$, sehingga hipotesis kedua "Diduga bahwa Good Corporate Governance mampu memoderasi pengaruh kinerja keuangan terhadap nilai perusahaan food and beverages yang terdaftar di Bursa Efek Indonesia", tidak teruji kebenarannya, karena Good Corporate Governance tidak memberikan kontribusi pengaruh kinerja keuangan terhadap nilai perusahaan.

\section{Uji Ketepatan Model (Uji F)}

Tabel 2. Hasil Uji F

\begin{tabular}{ccc}
\hline F & Signifikansi & $\mathbf{R}^{2}$ \\
\hline $\mathbf{7 . 4 2 4}$ & $\mathbf{0 . 0 0 2}$ & $\mathbf{0 , 2 5 7}$ \\
\hline
\end{tabular}

Berdasarkan tabel Uji $\mathrm{F}$ terlihat bahwa nilai

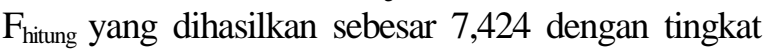
signifikan sebesar 0,002 kurang dari 5\% (sig < 5\%) maka $\mathrm{H}_{0}$ ditolak dan $\mathrm{H}_{1}$ diterima yang berarti model persamaan regresi yang terbentuk memiliki goodness of fit atau ketepatan model yang tinggi

\section{Koefisien Determinasi $\left(\mathbf{R}^{2}\right)$}

Besarnya pengaruh kinerja keuangan $\left(\mathrm{X}_{1}\right)$, Good Corporate Governance $\left(\mathrm{X}_{2}\right)$ dan interaksi antara kinerja keuangan dan Good Corporate Governance $\left(\mathrm{X}_{1} \mathrm{X}_{2}\right)$ terhadap nilai perusahaan $(\mathrm{Y})$ dapat dilihat dari nilai $\mathrm{R}^{2}$ yaitu sebesar 0,527 yang berarti variabel kinerja keuangan $\left(\mathrm{X}_{1}\right)$, Good Corporate Governance $\left(\mathrm{X}_{2}\right)$ dan interaksi antara kinerja keuangan dan Good Corporate Governance $\left(\mathrm{X}_{1} \mathrm{X}_{2}\right)$ mampu mempengaruhi nilai perusahaan $(\mathrm{Y})$ sebesar $25,7 \%$ dan sisanya $74,3 \%$ dijelaskan oleh variabel lain di luar model.

\section{Pengaruh Kinerja Keuangan Terhadap Nilai Perusahaan}

Dilihat dari hasil pengujian hipotesis yang telah dilakukan dapat diketahui bahwa secara parsial kinerja keuangan berpengaruh signifikan positif terhadap nilai perusahaan. Hal ini menunjukan bahwa semakin naik kinerja keuangan maka kemungkinan akan terjadinya kenaikan pula terhadap nilai perusahaan dan sebaliknya semakin menurun kinerja keuangan, maka nilai perusahaanpun mengalami penurunan. Hipotesis yang diajukan menyatakan bahwa kinerja keuangan mempunyai pengaruh positif terhadap nilai perusahaan food and beverages yang terdaftar di Bursa Efek Indonesia terbukti kebenarannya.

Dari hasil penelitian menunjukkan para investor melakukan overview suatu perusahaan dengan melihat rasio keuangan sebagai alat evaluasi investasi, karena rasio keuangan mencerminkan tinggi rendahnya nilai perusahaan. Jika investor ingin melihat seberapa besar perusahaan menghasilkan return atas investasi yang akan mereka tanamkan, yang akan dilihat pertama kali adalah rasio profitabilitas. Profitabilitas yang dalam penelitian ini diproksi melalui Return on Asset (ROA). ROA merupakan salah satu dari profitability ratio (rasio laba). ROA menunjukkan kemampuan perusahaan dalam menghasilkan laba dari aktiva yang digunakan atau diinvestasikan dalam suatu periode. Semakin tinggi rasio ini maka semakin baik produktivitas aset dalam memperoleh keuntungan bersih. Hal ini selanjutnya akan meningkatkan daya tarik perusahaan kepada investor. Peningkatan daya tarik perusahaan menjadikan perusahaan tersebut makin diminati investor, karena tingkat keuntungan akan semakin besar. Kinerja perusahaan yang meningkat akan turut meningkatkan nilai perusahaan.

Penelitian ini mendukung Modiglani dan Miller (dalam Ulupui, 2007) menyatakan bahwa nilai perusahaan ditentukan oleh Earnings Power dari asset perusahaan. Hasil positif menunjukkan bahwa semakin tinggi Earnings Power, maka semakin efisien perputaran asset dan atau semakin tinggi Profit Margin yang diperoleh perusahaan. Oleh karena itu, ROA merupakan salah satu faktor yang berpengaruh terhadap nilai perusahaan. Handoko (2011) juga menemukan bahwa ROA berpengaruh positif terhadap nilai perusahaan.

Berdasarkan hasil penelitian, maka dapat disimpulkan bahwa ketika tingkat keuntungan dalam kinerja keuangan yang dicapai perusahaan tersebut semakin baik maka akan berpengaruh positif dalam meningkatkan nilai perusahaan artinya semakin tinggi kinerja keuangan yang diukur dengan Return on Asset (ROA) maka semakin baik produktivitas asset dalam memperoleh keuntungan bersih. Terbukti bahwa jika penawaran tinggi maka akan meningkatkan permintaan. Hal ini selanjutnya akan meningkatkan daya tarik perusahaan kepada investor. Peningkatan daya tarik perusahaan menjadikan perusahaan tersebut makin diminati investor, karena tingkat keuntungan akan semakin besar. Oleh karena itu, Return on Asset merupakan salah satu faktor yang berpengaruh terhadap nilai perusahaan. 
Good Corporate Governance sebagai Variabel Pemoderasi

Dari hasil pengujian hipotesis yang telah dilakukan dapat diketahui bahwa secara parsial interaksi antara kinerja keuangan dan Good Corporate Governance tidak berpengaruh signifikan terhadap nilai perusahaan. Hal ini menunjukkan bahwa variabel Good Corporate Governance yang diproksikan dengan kepemilikan manajerial bukanlah variabel yang memoderasi pengaruh kinerja keuangan terhadap nilai perusahaan.

Hasil ini tidak sesuai dengan hipotesis yang diajukan yaitu Good Corporate Governance mampu memoderasi pengaruh kinerja keuangan terhadap nilai perusahaan food and beverages yang terdaftar di Bursa Efek Indonesia, tidak terbukti kebenarannya. Dilihat dari persamaan regresi yang diperoleh menunjukkan bahwa Good Corporate Governance tidak mempunyai pengaruh terhadap hubungan kinerja keuangan dengan nilai perusahaan. Menurut Demsetz (1983) (dalam Mook \& Ryu, 2003) yang menunjukkan bahwa dalam tahap tertentu, tingkat kepemilikan manajerial tidak selalu berpengaruh terhadap nilai perusahaan, ada hubungan negatif antara kepemilikan manajerial dan nilai perusahaan.

Hasil ini mungkin disebabkan oleh kepemilikan manajerial tidak tepat sebagai proksi dari Good Corporate Governance. Hal ini karena struktur kepemilikan manajerial di Indonesia masih sangat kecil dan didominasi oleh keluarga. Hasil penelitian ini menunjukkan bahwa masih banyak pemegang saham yang merangkap jabatan sebagai Dewan Komisaris dalam suatu perusahaan. Mereka memiliki pertimbangan bahwa adanya salah satu anggota pemegang saham yang merangkap sebagai anggota Dewan Komisaris maka akan mempermudah pengawasan kinerja manajemen.

Selain itu dengan adanya jabatan ganda maka akan menimbulkan efisiensi biaya keagenan bagi pemegang saham. Hal ini karena pemegang saham belum bisa memberikan kepercayaan penuh mengenai jalannya perusahaan kepada manajemen perusahaan. Di samping itu, pemegang saham menganggap Dewan Komisaris tidak memiliki pengetahuan yang cukup mengenai perusahaan mereka.

Hasil penelitian ini didukung oleh penelitian sebelumnya, yaitu penelitian Carningsih (2009) yang menyatakan bahwa Good Corporate Governance merupakan variabel pemoderasi tidak terbukti berpengaruh terhadap nilai perusahaan, sehingga dapat disimpulkan bahwa Dewan Komisaris dan Direktur sebagai variabel moderasi atas hubungan kinerja keuangan terhadap nilai perusahaan tidak mampu memoderasi hubungan kedua variabel tersebut.

\section{SIMPULAN DAN SARAN}

Berdasarkan hasil analisis regresi linier berganda, maka kesimpulan yang diperoleh adalah 1) Kinerja keuangan yang diukur dengan ROA mampu meningkatkan nilai perusahaan food and beverages yang terdaftar di Bursa Efek Indonesia. Hal ini menunjukkan bahwa semakin tinggi kinerja keuangan, maka semakin baik nilai perusahaan tersebut. Terbukti bahwa jika penawaran tinggi maka akan meningkatkan permintaan. Hal ini selanjutnya akan meningkatkan daya tarik perusahaan kepada investor. Peningkatan daya tarik perusahaan menjadikan perusahaan tersebut makin diminati investor, karena tingkat keuntungan akan semakin besar. 2) Good Corporate Governance tidak mampu memoderasi pengaruh kinerja keuangan terhadap nilai perusahaan food and beverages yang terdaftar di Bursa Efek Indonesia. Hal ini menunjukkan bahwa variabel Good Corporate Governance yang diproksikan dengan kepemilikan manajerial bukanlah variabel pemoderasi. Disebabkan oleh karena struktur kepemilikan manajerial di Indonesia masih sangat kecil dan didominasi oleh keluarga. Pemilik (principal/investor/ pemegang saham) belum bisa memberikan kepercayaan penuh mengenai jalannya perusahaan kepada manajemen perusahaan. Di samping itu, pemegang saham menganggap bahwa Dewan Komisaris tidak memiliki pengetahuan yang cukup mengenai perusahaan mereka.

Bagi penelitian selanjutnya, peneliti hendaknya menambah jumlah sampel penelitian dan juga melibatkan sektor industri yang lain agar mencerminka reaksi dari pasar modal secara keseluruhan. Penelitian selanjutnya dapat menggunakan proksi kinerja keuangan dan proksi GCG yang lain, misalnya Price Book Value, leverage, Komisaris Independen, Komite Audit atau kriteria lain yang telah ditetapkan.

\section{DAFTAR REFERENSI}

Ang, R. 1997. Buku Pintar Pasar Modal Indonesia. Jakarta: Mediasoft Indonesia.

Beiner, S., Drobetz, W., Schmid, F. \& Zimmerman, H. 2003. Is Board Size An Independent Corporate Governance Mechanism? Working Paper, (http://www.wwz.unibaz.ch/cofi/publications/ paper/2003/06.03.pdf, diakses 12 April 2011).

Brigham, E.F. \& Gapenski, L.C. 1996. Intermediate Financial Management. Fifth Edition. Orlando: The Dryden Press. 
Brigham, E.F. \& Houston, J.F. 2006. Dasar-Dasar Manajemen Keuangan. Edisi Kesepuluh. Jakarta: Penerbit Salemba Empat.

Carningsih. 2009. Pengaruh Good Corporate Governance Terhadap Hubungan Antara Kinerja Keuangan Dengan Nilai Perusahaan (Studi Kasus Pada Perusahaan Property dan Real Estate yang Terdaftar di Bursa Efek Indonesia. Jakarta: Fakultas Ekonomi, Universitas Gunadarma. (http://www.gunadarma.ac.id/library/ articles/graduate/economy/2009/Artikel_2020 5242.pdf diakses 22 Januari 2011).

Daniri, M.A. 2005. Good Corporate Governance: Konsep dan Penerapannya dalam Konteks Indonesia. Jakarta: Ray Indonesia.

Haidar, I.J. 2009. Investor Protections and Economic Growth, Economics Letters. Elsevier, 103(1): $1-4$.

Handoko, Y. 2011. Pengaruh Kinerja Keuangan Terhadap Nilai Perusahaan Dengan Pengungkapan Corporate Social Responsibility dan Good Corporate Governance sebagai Variabel Pemoderasi. Jakarta: Fakultas Ekonomi, Universitas Gunadarma. (http://www. papers.gunadarma. ac.id/index.php/economy/article/view/876/8 34, diakses 22 Januari 2011).

Hidayah, E. 2008. Pengaruh Kualitas Pengungkapan Informasi Terhadap Hubungan Antara Penerapan Corporate Governance Dengan Kinerja Perusahaan Di Bursa Efek Jakarta. Jurnal Akuntansi dan Auditing Indonesia. 12(1).

Husnan, S. 2000. Manajemen Keuangan Teori dan Penerapan. Yogyakarta: BPFE.

Jensen, M. C. \& Meckling, W. H. 1976. Theory of the Firm: Managerial Behavior, Agency Costs and Ownership Structure. Journal of Financial Economics, 3: 305-360.

Kementerian Perindustrian. 2012. Pasar Makanan \& Minuman Diprediksi Tumbuh 10\%. (http://www. kemenperin.go.id/artikel/663/Pasar-Makanan\&-Minuman-Diprediksi-Tumbuh-10, diakses Agustus 2012)

Kementerian Hukum dan HAM RI. 2007. UndangUndang Republik Indonesia No. 40 Tentang Perseroan Terbatas. (http://www.lawindo.biz/ Undang-Undang\%20No.\%2040\%20TH\%2020 07\%20tentang\%20Perseroan\%20Terbatas.pdf, diakses 2 Januari 2010).
Keputusan Menteri Badan Usaha Milik Negara. 2002. Tentang penerapan Praktek Good Corporate Governance pada Badan Usaha Milik Negara (BUMN). (http://www.iicg.org/asset/doc/Kep men_BUMN_2002_117_Praktek_GCG_BU MN.pdf, diakses Juli 2010)

La Porta, R., Lopez-De-Silanes, F. \& Shleifer, A. 1999. Corporate Ownership Around the Word. The Journal of Finance, LIV (2).

Midiastuti, Puspa, P. \& Machfoedz, M. 2003. Analisis Hubungan Mekanisme Corporate Governance dan Indikasi Manajmen Laba. Makalah ini disajikan dalam: Simposium Nasional Akuntansi VI, Surabaya.

Mook, L.S. \& Ryu, K. 2003. Management Ownership and Firm's Value: An Empirical Analysis Using Panel Data. Social Science Research Network, Dicussion Paper No. 593 (http://papers. ssrn.com/sol3/papers.cfm?abstract_ id $=444420$, diakses 7 November 2010)

Riyadi, Y. 2012. Safeguard Lindungi Produk Lokal. Tribun News (http://batam.tribunnews.com/2012/ 07/18/safeguard-lindungi-produk-lokal, diakses 23 Juli 2012)

Solihin, I. 2009. Corporate Social Responsibility (CSR). Jakarta: Salemba Empat.

Suranta, E. \& Merdistuti, P.P. 2004. Income Smoothing, Tobin's Q, Agency Problems dan Kinerja Perusahaan. Makalah ini disajikan dalam: Simposium Nasional Akuntansi VII. Bali, 2 - 3 Desember.

Ulupui, I.G.K.A. 2007. Analisis Pengaruh Rasio Likuiditas, Leverage, Aktivitas, dan Profitabilitas terhadap return saham (Studi pada Perusahaan Makanan dan Minuman dengan Kategori Industri Barang Konsumsi di Bursa Efek Jakarta). Jurnal Akuntansi dan Bisnis, 2(1): 88-102.

Van Horne \& James, C. 1995. Fundamental of Financial Management, New York: Prentice Hall.

Wahidahwati. 2002. Pengaruh Kepemilikan Manajerial dan Kepemilikan Institusional pada kebijakan Hutang Perusahaan: Sebuah Perspektif Theory Agency, Jurnal Riset Akuntansi, 5 (1).

Weston, J.F. \& Copeland, T.E. 1991. Manajemen Keuangan. Edisi Kedelapan, Surabaya: Erlangga. 